\title{
ANIMAL RESEARCH PAPER Influence of cellulase addition to dairy goat diets on digestion and fermentation, milk production and fatty acid content
}

\author{
R. ROJO ${ }^{1}$, A. E. KHOLIF ${ }^{2}$, A. Z. M. SALEM ${ }^{3 *}$, M. M. Y. ELGHANDOUR ${ }^{3}$, N. E. ODONGO ${ }^{4}$, \\ R. MONTES DE OCA ${ }^{3}$, N. RIVERO ${ }^{5}$ AND M. U. ALONSO ${ }^{3}$ \\ ${ }^{1}$ Centro Universitario UAEM Temascaltepec, Universidad Autónoma del Estado de México, Temascaltepec, 51300, \\ México \\ ${ }^{2}$ Dairy Science Department, National Research Centre, 33 Bohouth St. Dokki, Giza, Egypt \\ ${ }^{3}$ Facultad de Medicina Veterinaria y Zootecnia, Universidad Autónoma del Estado de México, Instituto literario N. 100, \\ C.P. 50000, Col. Centro, Toluca, Estado de México, Mexico \\ ${ }^{4}$ Department of Animal Sciences, School of Agriculture and Environmental Sciences, Pwani University, P. O. Box \\ 195-80108, Kilifi, Kenya \\ ${ }^{5}$ Institute of Agricultural Sciences, Autonomous University of Hidalgo, Tulancingo, Hidalgo, Mexico
}

(Received 2 January 2015; revised 12 May 2015; accepted 17 July 2015)

\section{SUMMARY}

Twenty four French Alpine goats $(39 \pm 2 \cdot 0 \mathrm{~kg})$ were individually housed in a completely randomized design and fed a basal diet containing $146 \mathrm{~g}$ crude protein and $356 \mathrm{~g}$ neutral detergent fibre (NDF)/kg in the absence (control-CTRL) or presence (CELL) of $2 \mathrm{ml}$ of cellulase/kg dry matter intake (DMI) for 70 days, which included a 10-day adaptation period. The feed was offered three times daily at 07.00,13.00 and $19.00 \mathrm{~h}$, but the single daily dose of cellulase was only fed at $07.00 \mathrm{~h}$. Goats were hand-milked daily; milk production recorded and samples taken for compositional analysis. During the last 5 days of the experimental period, goats from each group were individually housed in stainless steel metabolic cages to enable separate and total collection of faeces and urine for nutrient digestibility and ruminal fermentation determinations. Goats fed CELL had greater DMI and greater digestibility of dry matter (DM), organic matter and NDF than CTRL goats. CELL goats had greater ruminal $\mathrm{pH}$, concentration of acetic acid and concentration of propionic acid than CTRL goats. However, the concentration of ruminal butyric was lower in CELL goats compared with CTRL goats. CELL goats had greater milk yield, energy corrected milk, milk energy content, milk energy output and milk density than CTRL goats and the milk content for total solids, fat, protein and lactose were also greater for CELL goats than for the CTRL goats. The milk of CELL goats had greater palmitoleic acid, cis-10-heptadecanoic acid content and mono-saturated acids than the milk of CTRL goats and lower linoleic acid, linolenic acid contents and saturated fatty acids than the milk of CTRL goats. These results suggest that addition of $2 \mathrm{ml}$ cellulase $/ \mathrm{kg}$ DM of feed in the diet of lactating French Alpine goats elevated their milk production and improved its composition probably due to improved feed utilization.

\section{INTRODUCTION}

Many attempts have been made to improve the utilization of feeds by dairy cattle. In recent years, use of feed additives and enzymes in ruminant nutrition have gained elevated interest, e.g. yeast (Elghandour et al. 2014), phytogenic extracts (Cedillo et al. 2014; Salem et al. 2014) and fibrolytic enzymes (Alsersy

* To whom all correspondence should be addressed. Email: asalem70@yahoo.com et al. 2015; Salem et al. 2015; Valdes et al. 2015). Furthermore, feeding dairy animals on diets supplemented with fibre-degrading enzymes has been shown to improve feed utilization and animal performance (Khattab et al. 2011; Salem et al. 2013). However, the mode of action of these enzymes has not been fully elucidated.

Hydrolysis of dietary fibre before ingestion (Khattab et al. 2011), provision of readily fermentable substrates for ruminal micro-organisms (McAllister et al. 
2001) and synergistic enhancement of microbial enzyme activity in the rumen (Morgavi et al. 2000) have been suggested as possible modes of action. In addition, alteration of ruminal fermentation (Salem et al. 2015) and enhanced ruminal micro-organism attachment to and colonization of the plant cell wall (Wang et al. 2001) are other possibilities.

Although the results of applying fibrolytic enzymes in dairy cattle rations have been encouraging, they have also been inconsistent. Some studies showed elevated milk production and improved composition (Gado et al. 2009; Khattab et al. 2011) while others did not (Elwakeel et al. 2007; Dean et al. 2013). Although the reasons for this are unknown, some factors such as differences in enzyme activity, application rate and composition, stage of lactation, time of enzyme delivery, ruminal activity and enzyme stability, enzyme-feed specificity and the portion of the diet in which enzymes are applied have been implicated (Dean et al. 2013).

The objective of the present study, therefore, was to determine the effects of adding a fibrolytic enzyme cellulase in goat rations on feed intake, ruminal fermentation, nutrient digestibility, milk production and milk composition of French Alpine dairy goats fed a high fibre basal diet.

\section{MATERIALS AND METHODS}

All procedures involved in handling animals during the experimental period were conducted according to the official Mexican standards of animals care (NORMA Oficial Mexicana 1995).

\section{Study location}

The experiment was performed at the metabolic area of the Animal Science farm, and laboratory of animal nutrition of the Centro Universitario UAEMTemascaltepec, Universidad Autónoma del Estado de México, México $\left(19^{\circ} 02^{\prime} 04^{\prime \prime} \mathrm{N}, 100^{\circ} 02^{\prime} 14^{\prime \prime} \mathrm{W}\right.$, $1720 \mathrm{~m}$ a.s.l.). The climate is moderately humid with an average temperature of $15-18{ }^{\circ} \mathrm{C}$ and annual rainfall of 950-1000 mm.

\section{Animals, housing and feeding}

Twenty-four French Alpine dairy goats $(39 \pm 2 \cdot 0 \mathrm{~kg}$ initial live weight, 9 months old, first calving) were housed in individual pens provided with automatic feeders and waterers. Immediately after kidding, the goats were adapted to the pens and the basal diet (Table 1) for 10 days before starting the experiment, which lasted for 60 days. Goats were injected with $3 \mathrm{ml} /$ animal of fat-soluble vitamins (A, D, E; Vigantol, Bayer, Mexico City, Mexico) and treated with $0.5 \mathrm{ml}$ Ivermectin (Laboratory Sanfer, Mexico City, Mexico) per animal for internal and external parasites and the health of the animals monitored throughout the experiment.

A week before the start of the experiment, goats were weighed individually and assigned randomly to two treatments (12 goats per treatment) in a completely randomized design.

The treatments were: CTRL: basal diet without addition of cellulase; CELL: basal diet + Celluase $^{\circledR}$ plus (Dyadic ${ }^{\circledR}$ PLUS, Dyadic international, Inc., Jupiter, FL, USA) at $2 \mathrm{ml} / \mathrm{kg}$ dry matter (DM) of feed. The activity of the exogenous fibrolytic enzyme Celluase ${ }^{\circledR}$ plus was determined and contained 30000-36000 units of cellulase/g and 7500-10000 units of beta-glucanase/g.

Goats were offered a total mixed ration (TMR; Table 1) three times daily at 07.00, 13.00 and $19.00 \mathrm{~h}$. The TMR was balanced for minerals and vitamins and formulated to cover the nutrient requirements of goats according to NRC (1981) recommendations plus a margin of $0 \cdot 15$. The daily allocation of enzyme for each goat was mixed individually with the TMR and fed at $07.00 \mathrm{~h}$. Throughout the experimental period, the amount of feed offered was recorded and orts were collected daily and weighed for determination of daily feed intake. Additionally, feeds were sampled daily, composited weekly and dried at $60^{\circ} \mathrm{C}$ to constant weight and stored for later chemical analysis.

Nutrient digestibility, rumen fermentation and milk production

All goats from each group were housed individually in stainless steel metabolic cages at room temperature with free access to water during the last 5 days of the experimental period for nutrient digestibility and ruminal fermentation determinations. Beneath each cage were $4 \mathrm{~mm}$ stainless steel screens to retain faeces but let the urine through to enable separate and total collection of faeces and urine. Total faeces was collected once daily from each goat before the morning feeding, according to the methodology proposed by Stock et al. (1987), and stored at $-10^{\circ} \mathrm{C}$ for later analysis. A sample of about $150 \mathrm{~g}$ of faeces from each animal was taken daily and composited weekly. 
Table 1. Ingredients and chemical composition of the basal diet, offered to the French Alpine dairy goats during the first third of lactation

\begin{tabular}{lr}
\hline \hline & $\mathrm{g} / \mathrm{kg}$ \\
\hline Ingredients (g/kg DM) & \\
Sorghum grains & 171 \\
Maize grain & 171 \\
Wheat bran & 90 \\
Soybean meal & 90 \\
Urea & 12 \\
Molasses & 48 \\
Minerals and vitamins* & 18 \\
Maize stover & 80 \\
Alfalfa hay & 320 \\
Chemical composition (g/kg DM) & \\
Dry matter & 865 \\
Organic matter & 926 \\
Crude protein & 146 \\
Ether extract & 97 \\
Neutral detergent fibre & 356 \\
Acid detergent fibre & 307 \\
\hline \hline
\end{tabular}

* Mineral/vitamin premix contained: vitamin A (12 000 $000 \mathrm{IU})$, vitamin $\mathrm{D}_{3}(2500000 \mathrm{IU})$, vitamin $\mathrm{E}(15000 \mathrm{IU})$, vitamin $\mathrm{K}(2 \cdot 0 \mathrm{~g})$, vitamin $\mathrm{B}_{1}(2 \cdot 25 \mathrm{~g})$, vitamin $\mathrm{B}_{2}(7 \cdot 5 \mathrm{~g})$, vitamin $B_{6}(3.5 \mathrm{~g})$, vitamin $B_{12}(20 \mathrm{mg})$, pantothenic acid $(12.5 \mathrm{~g})$, folic acid $(1.5 \mathrm{~g})$, biotin (125 mg), niacin (45 g), iron $(50 \mathrm{~g})$, zinc $(50 \mathrm{~g})$, manganese $(110 \mathrm{~g})$, copper $(12 \mathrm{~g})$, iodine $(0 \cdot 30 \mathrm{~g})$, selenium $(200 \mathrm{mg})$, cobalt $(0 \cdot 20 \mathrm{~g})$.

The composited samples were dried in a forced air oven at $65^{\circ} \mathrm{C}$ for $72 \mathrm{~h}$ then ground through a $1 \mathrm{~mm}$ screen using a Wiley mill grinder (Wiley mill, Model 4, Thomas Scientific, Swedesboro, NJ, USA) and kept for later determination of compositional analysis. Additionally, rumen fluid was taken from the ventral sac of the rumen of each goat using a stomach tube $3 \mathrm{~h}$ after the morning feeding. The rumen samples (50 ml/goat) were filtered immediately using four layers of cheesecloth, strained and stored in $45 \mathrm{ml}$ glass bottles. The ruminal $\mathrm{pH}$ was then determined using a digital $\mathrm{pH}$ meter (GLP 22, Crison Instruments, Barcelona, Spain) and a few drops of toluene and paraffin oil added to each bottle to cover the surface and the bottles stored at $-18{ }^{\circ} \mathrm{C}$ for later individual volatile fatty acids (VFA) analyses.

Goats were hand-milked daily: milk production was measured in kg (electronic scale; OHAUS Mod. 5603, Mexico City, Mexico) and recorded. Milk was sampled twice weekly and preserved with potassium dichromate. The samples were stored at $4{ }^{\circ} \mathrm{C}$ before being sent to the laboratory for compositional analysis.

Chemical analysis and calculations

Dried samples were ground (sieve of $1 \mathrm{~mm}$ diameter, Wiley mill, Model 4, Thomas Scientific, Swedesboro, NJ, USA) and analysed for DM (ID 930.15), ash (ID 942.05), ether extract (ID 945.16) and crude protein (CP; ID 984.13) according to AOAC (1997). Collected feed, orts and faecal samples were analysed for neutral detergent fibre (NDF) and acid detergent fibre (ADF) contents (Van Soest et al. 1991) using an ANKOM200 Fibre Analyser unit (ANKOM Technology Corporation, Macedon, NY, USA).

The concentrations of acetic, propionic and butyric acids in rumen fluid were quantified as described in Hernandez et al. (2014) using crotonic acid as the internal standard using gas chromatography (model 5890, Hewlett Packard, Little Falls, DE, USA) with a capillary column $(30 \mathrm{~m} \times 0.25 \mathrm{~mm}$ internal diameter, $1 \mathrm{~m}$ phase thickness, Supelco Nukol; Sigma-Aldrich, Mississauga, ON, Canada), and flame ionization detection. Oven temperature was adjusted to $100^{\circ} \mathrm{C}$ for $1 \mathrm{~min}$, which was then increased by $20^{\circ} \mathrm{C} / \mathrm{min}$ to $140{ }^{\circ} \mathrm{C}$, and then by $8{ }^{\circ} \mathrm{C} / \mathrm{min}$ to $200^{\circ} \mathrm{C}$, and held at this temperature for $5 \mathrm{~min}$. The injector temperature was at $200{ }^{\circ} \mathrm{C}$ and the detector temperature at $250^{\circ}$ C. The carrier gas was Helium.

Ruminal methane $\left(\mathrm{CH}_{4}\right)$ production was calculated according to the equation of Moss et al. (2000) as:

$$
\begin{aligned}
\mathrm{CH}_{4}(\mathrm{~g} / \text { day })= & 0.45 \text { acetate }(\mathrm{mmol} / \mathrm{l}) \\
& -0.275 \text { propionate }(\mathrm{mmol} / \mathrm{l}) \\
& +0.40 \text { butyrate }(\mathrm{mmol} / \mathrm{l})
\end{aligned}
$$

Milk samples were analysed for fat, crude protein and lactose using Milk-O-Scan 605 (Foss Electric, Hillerod, Denmark), which is based on infrared technology. For milk fatty acid profile determination, $150 \mathrm{ml}$ of milk from each goat (experimental unit) were taken and stored at $-20^{\circ} \mathrm{C}$ and then are lyophilized to make a composited sample for fatty acid profile determination by gas chromatography (model 5890, Hewlett Packard, Little Falls, DE, USA) according to Erwin et al. (1961).

Average fat, crude protein and lactose yields (g/day) were calculated by multiplying milk yield by fat, crude protein and lactose content $(\mathrm{g} / \mathrm{kg}$ ) of milk of each individual goat. The gross energy concentration in milk 
was calculated according to Tyrell \& Reid (1965) as described in Kholif et al. (2015) as:

$$
\begin{aligned}
\text { Milk energy }(\mathrm{MJ} / \mathrm{kg})= & 4.184 \times 2.204 \times[(41.63 \\
& \times \text { fat }(\mathrm{g} / \mathrm{kg})+24.13 \\
& \times \text { protein }(\mathrm{g} / \mathrm{kg})+21.60 \\
& \times \text { lactose }(\mathrm{g} / \mathrm{kg})-117 \cdot 2) \\
& / 10000]
\end{aligned}
$$

The milk energy output was then calculated as milk energy output $(\mathrm{MJ} /$ day $)=$ milk energy $(\mathrm{MJ} / \mathrm{kg}) \times$ milk yield (kg/day).

Energy corrected milk (ECM) was calculated according to Sjaunja et al. (1991) as:

$$
\begin{aligned}
\mathrm{ECM}(\mathrm{kg} / \text { day })= & \text { milk }(\mathrm{kg} / \text { day }) \times[38 \cdot 3 \times \text { fat }(\mathrm{g} / \mathrm{kg}) \\
& +24 \cdot 2 \times \text { protein }(\mathrm{g} / \mathrm{kg})+16 \cdot 54 \\
& \times \text { lactose }(\mathrm{g} / \mathrm{kg})+20 \cdot 7] / 3140
\end{aligned}
$$

\section{Statistical analyses}

The nutrient intake and digestibility, ruminal fermentation parameters and milk yield and composition data were analysed with the PROC MIXED procedure of SAS (SAS Institute 2006) in which a completely randomized design was used with the statistical model:

$$
Y_{i j}=\mu+T_{i}+E_{i j}
$$

where $Y_{i j}$ is every observation of the $j$ th goat assigned to $i$ th treatment, $T_{i}$ is the treatment effect and $E_{i j}$ is the residual error.

Comparisons of results were performed using Tukey's test at $P<0.05$ (Steel \& Torrie 1980).

\section{RESULTS}

Feed intake, digestion and ruminal fermentation

Feed intake (kg/day), digestion (g digested/g ingested) and ruminal fermentation data are summarized in Table 2. Goats fed the CELL diet had greater DM intake (DMl; $P=0.049$ ), organic matter (OM) intake $(P=0.049)$ and NDF intake $(P=0.049)$ than CTRL goats (Table 2). The digestibility of DM, OM and NDF for CELL goats was also greater $(P<0 \cdot 001)$ than for CTRL goats. Additionally, the ruminal $\mathrm{pH}$ for CELL goats was greater $(P=0 \cdot 013)$ than for CTRL goats. CELL goats had greater concentration $(\mathrm{mmol} / \mathrm{l})$ of acetic acid $(P<0 \cdot 001)$ and concentration $(\mathrm{mmol} / \mathrm{l})$ of propionic acid $(P=0.007)$ than the CTRL goats.
However, the concentration of ruminal butyric $(\mathrm{mmol} / \mathrm{l})$ was lower $(P<0 \cdot 001)$ in CELL goats compared with CTRL goats (Table 2).

Milk production and composition

Milk yields (kg/day) and composition $(\mathrm{g} / \mathrm{kg}$ ) are presented in Table 3. CELL goats had greater milk yield $(P=0.042), \quad$ ECM $(P=0.001)$, milk energy content $(\mathrm{MJ} / \mathrm{kg}, P=0.008)$, milk energy output $(\mathrm{MJ} /$ day, $P=0.001)$ and milk density $(\mathrm{g} / \mathrm{ml}, P=0.003)$ than CTRL goats. Additionally, the milk content for total solids $(P=0.008)$, fat $(P=0.016)$, protein $(P=$ $0.003)$ and lactose $(P=0.05)$ were greater for CELL goats than for the CTRL goats. The same trends were noted for daily total solids $(P=0 \cdot 001)$, fat $(P=0 \cdot 001)$, protein $(P=0.001)$ and lactose $(P=0.002)$ yields. Feeding efficiency expressed as ECM/DMI tended to be greater $(P=0.066)$ for CELL goats than for CTRL goats; however, when expressed as milk yield/DMI, there were no differences (Table 3).

Milk fatty acid profiles

The milk fatty acid profiles (g/100 g of total esterified fatty acids) are summarized in Table 4 . The milk of CELL goats had greater palmitoleic acid $(P<0 \cdot 001)$, cis-10-heptadecanoic acid contents $(P=0 \cdot 021)$ and mono-saturated fatty acid $(P=0 \cdot 043)$ concentrations than the milk of CTRL goats, and lower linoleic acid $(P=0.035)$, linolenic acid $(P=0.023)$ and saturated fatty acid content $(P=0.047)$ than the milk of CTRL goats. CELL goat milk tended to have lower oleic acid $(P=0.073)$, greater $(P=0.072)$ capric acid and lower short-chain fatty acids $(P=0 \cdot 097)$ than CTRL goat milk (Table 4).

\section{DISCUSSION}

Feed intake

Goats supplemented with CELL consumed about 11\% more DM, OM and NDF compared with CTRL goats. Greater nutrient intake was mirrored by greater nutrient (i.e., DM, OM and NDF) digestibility. These results are consistent with the previous results of Salem et al. (2013), which can be explained by the greater nutrient digestibility, particularly fibre, and Gado et al. (2009) obtained 13\% more DMI due to enzyme addition in dairy cow diets. This is in contrast to Dean et al. (2013) who observed no difference in 
Table 2. Feed intake, nutrient digestibility and ruminal fermentation of French Alpine dairy goats fed on the basal diet in the absence (CTRL) or presence of cellulase (CELL) enzyme $(2 \mathrm{ml} / \mathrm{kg}$ DMI) during the first third of lactation (60 days) ( $n=12$ per treatment)

\begin{tabular}{|c|c|c|c|c|}
\hline & \multicolumn{2}{|c|}{ Diets } & \multirow[b]{2}{*}{ S.E.M. } & \multirow[b]{2}{*}{$P$ value } \\
\hline & CTRL & CELL & & \\
\hline \multicolumn{5}{|l|}{ Intake (kg/day) } \\
\hline Dry matter & $3 \cdot 1$ & $3 \cdot 5$ & $0 \cdot 12$ & $0 \cdot 049$ \\
\hline Organic matter & $2 \cdot 9$ & $3 \cdot 2$ & $0 \cdot 11$ & 0.049 \\
\hline Neutral detergent fibre & $1 \cdot 11$ & $1 \cdot 23$ & 0.041 & $0 \cdot 049$ \\
\hline \multicolumn{5}{|c|}{ Digestibility (g digested/g ingested) } \\
\hline Dry matter & 0.74 & 0.77 & $0 \cdot 011$ & $0 \cdot 001$ \\
\hline Organic matter & $0 \cdot 76$ & $0 \cdot 80$ & $0 \cdot 013$ & $0 \cdot 001$ \\
\hline Neutral detergent fibre & $0 \cdot 62$ & $0 \cdot 68$ & $0 \cdot 011$ & $<0 \cdot 001$ \\
\hline \multicolumn{5}{|l|}{ Ruminal fermentation } \\
\hline $\mathrm{pH}$ & $6 \cdot 44$ & $6 \cdot 62$ & $0 \cdot 046$ & $0 \cdot 013$ \\
\hline Acetate $(\mathrm{A} ; \mathrm{mmol} / \mathrm{l})$ & 45 & 47 & $1 \cdot 2$ & $<0 \cdot 001$ \\
\hline Propionate $(\mathrm{P} ; \mathrm{mmol} / \mathrm{l})$ & $14 \cdot 2$ & $15 \cdot 8$ & $0 \cdot 39$ & $0 \cdot 007$ \\
\hline Butyrate $(\mathrm{mmol} / \mathrm{l})$ & $9 \cdot 5$ & $7 \cdot 3$ & $0 \cdot 28$ & $<0 \cdot 001$ \\
\hline $\mathrm{A} / \mathrm{P}$ ratio & $3 \cdot 17$ & 3.03 & $0 \cdot 075$ & $0 \cdot 174$ \\
\hline $\mathrm{CH}_{4}$ (g/day) & $20 \cdot 1$ & $19 \cdot 9$ & $0 \cdot 19$ & $0 \cdot 483$ \\
\hline
\end{tabular}

Table 3. Milk yield and composition of French Alpine dairy goats fed on the basal diet in the absence (CTRL) or presence of cellulase (CELL) enzyme $(2 \mathrm{ml} / \mathrm{kg}$ DMI) during the first third of lactation (60 days) $(n=12$ per treatment)

\begin{tabular}{lcccc}
\hline \hline & \multicolumn{2}{c}{ Diets } & & \\
\cline { 2 - 3 } & CTRL & CELL & S.E.M. & $P$ value \\
\hline Milk & & & & \\
$\quad$ Yield (kg/day) & $3 \cdot 1$ & $3 \cdot 4$ & $0 \cdot 13$ & $0 \cdot 042$ \\
Energy corrected milk (ECM, kg/day) & $2 \cdot 6$ & $3 \cdot 3$ & $0 \cdot 12$ & $0 \cdot 001$ \\
Milk energy content (MJ/kg) & $2 \cdot 8$ & $3 \cdot 1$ & $0 \cdot 18$ & $0 \cdot 008$ \\
Milk energy output (MJ/day) & $8 \cdot 3$ & $10 \cdot 5$ & $0 \cdot 37$ & $0 \cdot 001$ \\
Density (g/ml) & $1 \cdot 026$ & $1 \cdot 028$ & $0 \cdot 0012$ & $0 \cdot 003$ \\
Milk composition (g/kg) & & & & \\
Total solids & 104 & 114 & $2 \cdot 6$ & $0 \cdot 008$ \\
Fat & 34 & 40 & $1 \cdot 5$ & $0 \cdot 016$ \\
Protein & 29 & 31 & $1 \cdot 4$ & $0 \cdot 003$ \\
Lactose & 41 & 44 & $2 \cdot 0$ & $0 \cdot 050$ \\
Milk component yield (kg/day) & & & & \\
Total solids & 315 & 392 & $13 \cdot 3$ & $0 \cdot 001$ \\
Fat & 103 & 136 & $5 \cdot 9$ & $0 \cdot 001$ \\
Protein & 87 & 105 & $3 \cdot 4$ & $0 \cdot 001$ \\
Lactose & 125 & 151 & $5 \cdot 1$ & $0 \cdot 002$ \\
Feed efficiency & & & $0 \cdot 053$ & $0 \cdot 772$ \\
Milk (milk/DMl) & $0 \cdot 99$ & $1 \cdot 01$ & $0 \cdot 044$ & $0 \cdot 066$ \\
Energy corrected milk (ECM/DMl) & $0 \cdot 84$ & $0 \cdot 96$ & & \\
\hline \hline
\end{tabular}


Table 4. Milk fatty acid profile ( $\mathrm{g} / 100 \mathrm{~g}$ of total fatty acids esterified) of French Alpine dairy goats fed on the basal diet in the absence (CTRL) or presence of cellulase (CELL) enzyme $(2 \mathrm{ml} / \mathrm{kg} D M I)$ during the first third of lactation (60 days) ( $n=12$ per treatment)

\begin{tabular}{|c|c|c|c|c|}
\hline & \multicolumn{2}{|c|}{ Diets } & \multirow[b]{2}{*}{ S.E.M. } & \multirow[b]{2}{*}{$P$ value } \\
\hline & CTRL & CELL & & \\
\hline Butyric acid (C4:0) & $1 \cdot 76$ & $1 \cdot 66$ & $0 \cdot 073$ & $0 \cdot 355$ \\
\hline Caproic acid (C6:0) & $2 \cdot 34$ & $2 \cdot 26$ & $0 \cdot 061$ & $0 \cdot 340$ \\
\hline Caprylic acid (C8:0) & $2 \cdot 95$ & $2 \cdot 87$ & $0 \cdot 080$ & 0.479 \\
\hline Capric (C10:0) & $11 \cdot 2$ & $10 \cdot 5$ & $0 \cdot 26$ & 0.072 \\
\hline Undecanoic (C11:0) & $0 \cdot 40$ & $0 \cdot 39$ & $0 \cdot 016$ & $0 \cdot 877$ \\
\hline Lauric (C12:0) & $5 \cdot 4$ & $5 \cdot 0$ & $0 \cdot 16$ & $0 \cdot 113$ \\
\hline Tridecanoic (C13:0) & $0 \cdot 24$ & $0 \cdot 23$ & $0 \cdot 010$ & 0.473 \\
\hline Myristic (C14:0) & $11 \cdot 4$ & $11 \cdot 3$ & $0 \cdot 16$ & $0 \cdot 498$ \\
\hline Myristoleic (C14:1) & $0 \cdot 189$ & $0 \cdot 169$ & $0 \cdot 0092$ & $0 \cdot 134$ \\
\hline Pentadecanoic (C15:0) & $1 \cdot 11$ & $1 \cdot 10$ & $0 \cdot 037$ & $0 \cdot 781$ \\
\hline Palmitic (C16:0) & $28 \cdot 5$ & $27 \cdot 6$ & $0 \cdot 68$ & $0 \cdot 376$ \\
\hline Palmitoleic (C16:1) & $1 \cdot 06$ & $1 \cdot 22$ & $0 \cdot 023$ & $<0 \cdot 001$ \\
\hline Heptadecanoic (C17:0) & 0.97 & $1 \cdot 01$ & $0 \cdot 031$ & $0 \cdot 432$ \\
\hline Cis-10-heptadecanoic (C17:1) & $0 \cdot 29$ & $0 \cdot 37$ & $0 \cdot 023$ & $0 \cdot 021$ \\
\hline Stearic $(\mathrm{C} 18: 0)$ & $8 \cdot 7$ & $9 \cdot 4$ & $0 \cdot 40$ & $0 \cdot 247$ \\
\hline Oleic (C18:1) & $18 \cdot 9$ & $20 \cdot 5$ & $0 \cdot 57$ & 0.073 \\
\hline Linoleic (C18:2) & $2 \cdot 9$ & $2 \cdot 6$ & $0 \cdot 12$ & 0.035 \\
\hline Linolenic (C18:3) & $0 \cdot 53$ & $0 \cdot 44$ & $0 \cdot 028$ & 0.023 \\
\hline Conjugated linoleic acids & $0 \cdot 68$ & $0 \cdot 76$ & $0 \cdot 050$ & $0 \cdot 231$ \\
\hline Arachidonic acid (C20:4) & $0 \cdot 39$ & $0 \cdot 43$ & $0 \cdot 047$ & $0 \cdot 600$ \\
\hline Short-chain fatty acids & $18 \cdot 3$ & $17 \cdot 3$ & $0 \cdot 39$ & 0.097 \\
\hline Medium-chain fatty acids & $49 \cdot 6$ & $48 \cdot 5$ & $0 \cdot 64$ & $0 \cdot 234$ \\
\hline Long-chain fatty acids & $32 \cdot 2$ & $34 \cdot 0$ & $0 \cdot 79$ & $0 \cdot 112$ \\
\hline Saturated fatty acids (SFA) & $75 \cdot 0$ & $73 \cdot 4$ & $0 \cdot 55$ & 0.047 \\
\hline Mono-saturated acids & $20 \cdot 5$ & $22 \cdot 2$ & $0 \cdot 58$ & 0.043 \\
\hline Poly-saturated fatty acids (PSFA) & $4 \cdot 5$ & $4 \cdot 2$ & $0 \cdot 18$ & $0 \cdot 200$ \\
\hline PSFA/SFA & $0 \cdot 060$ & $0 \cdot 057$ & $0 \cdot 0025$ & $0 \cdot 346$ \\
\hline
\end{tabular}

feed intake of dairy cows supplemented with fibrolytic enzyme.

\section{Nutrient digestibility}

One of the main aims of adding cellulolytic enzymes in ruminant diets is to improve fibre digestion (Alsersy et al. 2015; Salem et al. 2015). In the present study, greater DM ( 4\%), OM ( 5\%) and NDF ( 9\%) digestibility were obtained with CELL addition compared with CTRL diets. This is consistent with previous studies, which reported greater nutrient digestibility due to enzyme addition (Khattab et al. 2011; Salem et al. 2013). Although the exact mode of action of the enzyme has not been elucidated, it has been suggested that higher rate of ruminal digestion of the potentially digestible NDF fraction (Yang et al. 1999), changes in the site of nutrient digestion (Kung et al. 2000), changes in gut viscosity (Hristov et al. 2000), altered ruminal fermentation (Khattab et al. 2011), enhanced attachment and colonization to the plant cell wall by ruminal micro-organisms (Wang et al. 2001) and complementary actions with ruminal enzyme (Morgavi et al. 2000) are possible causes of greater nutrient digestibility.

However, greater fibre digestion is unlikely to be the result of supplemental enzyme activity alone because the contribution of added exogenous enzymes to total ruminal activity is relatively small (Beauchemin et al. 2004). Moreover, elevated numbers of non-fibrolytic and fibrolytic bacteria in rumen fluid, which elevates microbial biomass, and provides more total polysaccharidase activity to digest feedstuffs (Wang et al. 2001; Giraldo et al. 2008) has not been 
explained. The Celluase ${ }^{\circledR}$ plus product used in the present study contained cellulase and beta-glucanase, which has been shown to have positive effects on digestion of NDF in TMR, although the results are inconsistent. Some studies (Gado et al. 2009; Khattab et al. 2011; Salem et al. 2013) reported greater nutrient digestibility, particularly fibre, with enzyme addition to the diets of dairy goats, dairy cows and feedlot cattle, but others did not (Giraldo et al. 2008; Dean et al. 2013). Dean et al. (2013) showed that total tract apparent digestibility of DM, NDF and CP were unaffected when the diet of dairy cows was supplemented with fibrolytic enzyme.

\section{Ruminal fermentation}

Goats fed the CELL diet showed higher ruminal $\mathrm{pH}$ compared with the CTRL goats. Ruminal $\mathrm{pH}$ is one of the most important determinants of nutrient digestion particularly fibre digestion, which is modulated via the effect it has on bacterial attachment to fibre substrates because fibrolytic bacteria are very sensitive to ruminal $\mathrm{pH}$ changes (Sung et al. 2007). Higher ruminal $\mathrm{pH}$ is more suitable for fibrolytic microbial activity than low ruminal $\mathrm{pH}$, which changes the rumen microbial population from fibrolytic to amylolytic (Tajima et al. 2001). In contrast, Khattab et al. (2011) reported no change in ruminal $\mathrm{pH}$ due to enzyme addition to the diet of dairy goats.

In the present study, ruminal concentrations of propionic and acetic acids were $\sim 12$ and $\sim 6 \%$ higher, respectively, whereas butyric acid was $\sim 31 \%$ lower for the CELL goats compared with CTRL goats, suggesting improved ruminal fibre fermentation. Gado et al. (2009) and Salem et al. (2013) obtained higher total and individual VFA concentrations when animals were supplemented with enzymes in their diets, suggesting that enzyme addition may alter ruminal fermentation (Khattab et al. 2011; Salem et al. 2013). The shift in ruminal fermentation may be a result of altered fibre structure, which could stimulate microbial colonization (Giraldo et al. 2008) or a shift in the species profile of fibre-colonizing bacteria as a response to enzyme addition (Wang et al. 2001).

The higher concentration of propionic acid in the rumen of CELL goats may also suggest synergism between exogenous enzymes in the feed and lactic acid bacteria in the rumen (Gado et al. 2009). Higher propionic acid concentration could elevate precursor availability and improve nutrient utilization, particularly for dairy goats in early lactation when nutrient intake lags behind nutrient demand (Eun et al. 2007), possibly due to fermentation of sugars released via cell wall hydrolysis by enzymes. The results of the present study suggest that addition of cellulase enzyme in the diet made the fermentation more gluconeogenic, and thereby improved the energetic efficiency of ruminal fermentation. Moreover, the greater concentration of acetic acid in the rumen fluid of CELL goats suggests that $\mathrm{CH}_{4}$ production was also greater, since acetic acid production is associated with the release of hydrogen, which can be used by methanogens to form $\mathrm{CH}_{4}$ (Stewart et al. 1997) and results in a loss of energy to the host animal (Gado et al. 2009). However, calculated $\mathrm{CH}_{4}$ production data do not support this hypothesis. Although only a few studies have investigated the effects of exogenous enzymes on $\mathrm{CH}_{4}$ production, the results are conflicting (Togtokhbayar et al. 2015). Although the concentrations of individual VFA, and by extension total VFA, were greater for the CELL goats than the CTRL goats, this result did not affect ruminal $\mathrm{pH}$ which was also greater. The reasons for this are unclear.

Milk production and composition

Goats fed CELL diet had 13\% (3.44 v. 3.05 kg/day) greater milk production compared with CTRL goats. The same trend was observed for ECM, which was $26 \%$ greater $(3.29$ v. $2.61 \mathrm{~kg} /$ day $)$ for CELL goats compared with CTRL goats. Additionally, milk energy content and milk energy output were greater for CELL goats than CTRL goats. The greater milk production is a reflection of greater feed intake, nutrient digestibility and ruminal fermentation activities due to the feeding of enzymes (Gado et al. 2009; Khattab et al. 2011). Gado et al. (2009) reported 23\% greater milk production in dairy cows fed a TMR supplemented with enzymes at $40 \mathrm{~g} / \mathrm{cow} /$ day for 12 weeks.

In the present study, ruminal concentrations of propionic acid were greater for CELL goats than for CTRL goats. Since propionic acid is the precursor of glucose and lactose, studies suggest that increasing glucogenic precursors resulted in curvilinear elevated milk yield, linear elevated milk protein content and curvilinear decrease in milk fat content (Rigout et al. 2003). This is because propionic acid has greater energy available for milk production (Yang et al. 1999). Moreover, greater concentration of acetic acid in the ruminal fluid of CELL goats is the main reason for greater 
milk fat content (Gado et al. 2009). The greater milk fat content for CELL goats could also be related to the greater digestibility of NDF of this diet (Kholif et al. 2014). One of the most surprising results was the greater milk lactose content with enzyme addition. The effect on milk lactose percentage is unusual because the content of milk lactose is typically very constant and changes only slightly (Elwakeel et al. 2007). Rumen acetate is the main source for milk short-chain fatty acid synthesis, thereby sparing protein and increasing milk fat and protein content (Fuller 2004). Kholif et al. (2014) showed that elevated milk protein content was related to greater DM, OM and fibre digestibility. In contrast, Dean et al. (2013) did not report any differences in milk production and component yields by enzyme supplementation of the dairy cow diet.

In the present study, addition of enzyme did not alter the concentration of many fatty acids. The milk of CELL goats had greater mono-saturated fatty acids than the milk of CTRL goats and lower saturated fatty acids than the milk of CTRL goats. Milk fatty acids originated mainly from plasma $(\sim 60 \%)$ or by the de novo synthesis in the mammary gland from acetate and 2-hydroxybutyrate originating as a result of rumen fermentation involving acetyl CoA carboxylase enzymes and fatty acid synthetase (Kholif et al. 2014). Ruminants do not synthesize polyunsaturated acids; consequently their concentration in milk depends on the amount absorbed from the intestines. These results in the present study may be due to the altered contents of acetic and propionic acid production in rumen as a result of greater fibre digestion. The direct result of shifted VFA proportions could elevate precursor availability for fatty acid synthesis, particularly during early lactation when nutrient intake lags behind nutrient demand (Eun et al. 2007). Gado et al. (2009) reported that enzyme supplemented diet showed greater ruminal acetate, propionate and butyrate proportions.

It can be concluded that under the study conditions in the tropical regions of Mexico, addition of exogenous fibrolytic cellulase at $2 \mathrm{ml} / \mathrm{kg}$ DM in the diet of lactating French Alpine goats resulted in greater feed intake and nutrient digestibility and improved milk production and composition.

The authors acknowledge financial support from the IAEA, Vienna (Austria), Research Contract number MEX16307 within the D3.10.27 Coordinated Research Project. Kholif, A. E. thanks the National Council for Science and Technology (CONACyT,
Mexico) and The World Academy of Sciences (TWAS, Italy) to support his Postdoctoral fellowship at the Facultad de Medicina Veterinaria y Zootecnia, Universidad Autónoma del Estado de México.

\section{REFERENCES}

Alsersy, H., Salem, A.Z.M., Borhami, B. E., Olivares, J., Gado, H.M., Mariezcurrena, M.D., Yacuot, M.H., Kholif, A. E., El-Adawy, M. \& Hernandez, S. R. (2015). Effect of Mediterranean saltbush (Atriplex halimus) ensilaging with two developed enzyme cocktails on feed intake, nutrient digestibility and ruminal fermentation in sheep. Animal Science Journal 86, 51-58.

AOAC (1997). Official Methods of Analysis of the Association of Official Analytical Chemists, Vol. 1, 16th edn. Washington, DC: Association of Official Analytical Chemists.

Beauchemin, K. A., Colombatto, D., Morgavi, D. P., Yang, W. Z. \& RoDE, L. M. (2004). Mode of action of exogenous cell wall degrading enzymes for ruminants. Canadian Journal of Animal Science 84, 13-22.

Cedillo, J., VÁzquez-Armijo, J. F., González-Reyna, A., Salem, A. Z. M., Kholif, A. E., Hernández-MeléndeZ, J., Martínez-González, J.C., De Oca Jiménez, R.M., Rivero, N. \& López, D. (2014). Effects of different doses of Salix babylonica extract on growth performance and diet in vitro gas production in Pelibuey growing lambs. Italian Journal of Animal Science 13, 609-613.

Dean, D. B., Staples, C. R., Littell, R. C., Kim, S. \& AdESOGAN, A. T. (2013). Effect of method of adding a fibrolytic enzyme to dairy cow diets on feed intake digestibility, milk production, ruminal fermentation, and blood metabolites. Animal Nutrition and Feed Technology 13, 337-353.

Elghandour, M. M. Y., Vázquez Chagoyán, J. C., Salem, A. Z. M., Kholif, A. E., Martínez Castañeda, J. S., Camacho, L. M. \& Cerrillo-Soto, M. A. (2014). Effects of Saccharomyces cerevisiae at direct addition or pre-incubation on in vitro gas production kinetics and degradability of four fibrous feeds. Italian Journal of Animal Science 13, 295-301.

Elwakeel, E. A., Titgemeyer, E. C., Johnson, B. J., Armendariz, C. K. \& Shirley, J. E. (2007). Fibrolytic enzymes to increase the nutritive value of dairy feedstuffs. Journal of Dairy Science 90, 5226-5236.

Erwin, E. S., Marco, G. J. \& Emery, E. M. (1961). Volatile fatty acid analysis of blood, rumen fluid by gas chromatography. Journal of Dairy Science 44, 1768-1776.

Eun, J.-S., Beauchemin, K. A. \& Schulze, H. (2007). Use of an in vitro fermentation bioassay to evaluate improvements in degradation of alfalfa hay. Animal Feed Science and Technology 35, 315-328.

Fuller, M.F. (2004). The Encyclopedia of Farm Animal Nutrition. Wallingford, Oxon, UK: CABI Publishing.

Gado, H. M., Salem, A. Z. M., Robinson, P. H. \& Hassan, M. (2009). Influence of exogenous enzymes on nutrient digestibility, extent of ruminal fermentation as well as milk production and composition in dairy cows. Animal Feed Science and Technology 154, 36-46. 
Giraldo, L.A., Tejido, M. L., Ranilla, M. J., Ramos, S. \& CARro, M. D. (2008). Influence of direct-fed fibrolytic enzymes on diet digestibility and ruminal activity in sheep fed a grass hay-based diet. Journal of Animal Science 86, 1617-1623.

Hernandez, P., Salem, A. Z. M., López, S., Sun, X. Z., Rojo, R., Camacho, L. M., Elghandour, M. M. Y. \& Ronquillo, M. G. (2014). Influence of Salix babylonica and Leucaena leucocephala leaf extracts on ruminal fermentation characteristics, urinary purine derivative excretion and microbial protein synthesis of lambs. Livestock Science 163, 80-84.

Hristov, A. N., McAllister, T.A. \& ChenG, K.-J. (2000). Intraruminal supplementation with increasing levels of exogenous polysaccharide-degrading enzymes: effects on nutrient digestion in cattle fed a barley grain diet. Journal of Animal Science 78, 477-487.

Khattab, H. M., Gado, H. M., Kholif, A. E., Mansour, A. M. \& KHOLIF, A. M. (2011). The potential of feeding goats sun dried rumen contents with or without bacterial inoculums as replacement for berseem clover and the effects on milk production and animal health. International Journal of Dairy Science 6, 267-277.

Kholif, A. E., Khattab, H. M., El-Shewy, A. A., Salem, A. Z. M., Kholif, A.M., El-Sayed, M.M., Gado, H.M. \& MariezcurrenA, M.D. (2014). Nutrient digestibility, ruminal fermentation activities, serum parameters and milk production and composition of lactating goats fed diets containing rice straw treated with Pleurotus ostreatus. Asian-Australasian Journal of Animal Sciences 27, 357-364.

Kholif, A. E., Gouda, G. A., Morsy, T.A., Salem, A. Z. M., Lopez, S. \& Kholif, A. M. (2015). Moringa oleifera leaf meal as a protein source in lactating goat's diets: feed intake, digestibility, ruminal fermentation, milk yield and composition, and its fatty acids profile. Small Ruminant Research 129, 129-137.

Kung, L., Treacher, R. J., Nauman, G. A., Smagala, A. M., ENDRES, K. M. \& COHEN, M. A. (2000). The effect of treating forages with fibrolytic enzymes on its nutritive value and lactation performance of dairy cows. Journal of Dairy Science 83, 115-122.

McAllister, T. A., Hristov, A. N., Beauchemin, K. A., Rode, L. M. \& CHENG, K.-J. (2001). Enzymes in ruminant diets. In Enzymes in Farm Animal Nutrition (Eds M. R. Bedford \& G. G. Partridge), pp. 273-298. Wallingford, Oxon, UK: CABI Publishing.

Morgavi, D. P., Nsereko, V. L., Rode, L. M., Beauchemin, K. A., McAllister, M. \& WANG, Y. (2000). A Trichoderma feed enzyme preparation enhances adhesion of Fibrobacter succinogenes to complex substrates but not to pure cellulose. In Proceedings of the 25th Conference on Rumen function, pp. 33. Chicago, Illinois, USA: Purina Mills Inc. (Abstract).

Moss, A. R., Jouany, J. P. \& Newbold, J. (2000). Methane production by ruminants: its contribution to global warming. Annales De Zootechnie 49, 231-253.

NORMA Oficial Mexicana (1995). Trato Humanitario en la Movilización de Animales: NOM-051-ZOO-1995. Diario Oficial de la Federacion 1998, 42-67.
NRC (1981). Nutrient Requirements of Goats: Angora, Dairy, and Meat Goats in Temperate and Tropical Countries. Washington, DC: National Academies Press.

Rigout, S., Hurtaud, C., Lemosquet, S., Bach, A. \& Rulquin, H. (2003). Lactational effect of propionic acid and duodenal glucose in cows. Journal of Dairy Science 86, 243-253.

Salem, A.Z.M., Gado, H.M., Colombatto, D. \& Elghandour, M.M.Y. (2013). Effects of exogenous enzymes on nutrient digestibility, ruminal fermentation and growth performance in beef steers. Livestock Science 154, 69-73.

Salem, A. Z.M., Kholif, A. E., Elghandour, M.M. Y., Buendía, G., Mariezcurrena, M. D., Hernandez, S. R. \& CAMACHO, L. M. (2014). Influence of oral administration of Salix babylonica extract on milk production and composition in dairy cows. Italian Journal of Animal Science 13, 10-14.

Salem, A. Z. M., Alsersy, H., Camacho, L. M., El-Adawy, M. M., Elghandour, M.M.Y., Kholif, A. E., Rivero, N., Alonso, M. U. \& Zaragoza, A. (2015). Feed intake, nutrient digestibility, nitrogen utilization, and ruminal fermentation activities in sheep fed Atriplex halimus ensiled with three developed enzyme cocktails. Czech Journal of Animal Science 60, 185-194.

SAS Institute (2006). SAS User's Guide: Statistics, version 9.0. Cary, NC: SAS Institute.

Sjaunja, L. O., Baevre, L., Junkkarinen, L., Pedersen, J. \& SetalA, J. (1991). A Nordic proposal for an energy corrected milk (ECM) formula. In Performance Recording of Animals: State of the Art 1990; 27th Biennial Session of the International Committee for Animal Recording (Eds P. Gaillon \& Y. Chabert), pp. 156-192. EAAP Publication 50. Wageningen, The Netherlands: Centre for Agricultural Publishing and Documentation (PUDOC).

Steel, R. G. D. \& Torrie, J.H. (1980). Principles and Procedures of Statistics: A Biometrical Approach. New York: McGraw-Hill Book Co.

Stewart, C. S., Flint, H. J. \& Byrant, M. P. (1997). The rumen bacteria. In The Rumen Microbial Ecosystem (Eds P. N. Hobson \& C. S. Stewart), pp. 10-72. New York, NY: Springer.

Stock, R. A., Brink, D. R., Britton, R. A., Goedeken, F. K., Sindt, M. H., Kreikemier, K. K., Bauer, M. L. \& Smith, K. K. (1987). Feeding combinations of high moisture corn and dry-rolled grain sorghum to finishing steers. Journal of Animal Science 65, 290-302.

Sung, H. G., Kobayashi, Y., Chang, J., Ha, A., Hwang, I. H. \& $\mathrm{HA}_{\mathrm{A}}$ J. K. (2007). Low ruminal $\mathrm{pH}$ reduces dietary fiber digestion via reduced microbial attachment. AsianAustralasian Journal of Animal Sciences 20, 200-207.

Tajima, K., Aminov, R. I., Nagamine, T., Matsui, H., Nakamura, M. \& BenNo, Y. (2001). Diet-dependent shifts in the bacterial population of the rumen revealed with real-time PCR. Applied and Environmental Microbiology 67, 2766-2774.

Togtokhbayar, N., Cerrillo, M. A., Rodríguez, G. B., Elghandour, M. M. M. Y., Salem, A. Z. M., Urankhaich, C., Jigjidpurev, S., Odongo, N.E. \& Kholif, A.E. (2015). Effect of exogenous xylanase on rumen in vitro gas production and degradability of wheat straw. Animal Science Journal 86, 765-771. 
Tyrell, H. F. \& Reid, J. T. (1965). Prediction of the energy value of cows' milk. Journal of Dairy Science $\mathbf{4 8}$, 1215-1223.

Valdes, K.I., Salem, A.Z.M., Lopez, S., Alonso, M. U., Rivero, N., Elghandour, M. M. Y., Domínguez, I. A., Ronquillo, M. G. \& KHolif, A. E. (2015). Influence of exogenous enzymes in presence of Salix babylonica extract on digestibility, microbial protein synthesis and performance of lambs fed maize silage. Journal of Agriculture Science, Cambridge 153, 732-742.

Van Soest, P.J., Robertson, J. B. \& Lewis, B. A. (1991). Methods for dietary fibre, neutral detergent fibre, and non-starch carbohydrates in relation to animal nutrition. Journal of Dairy Science 74, 3583-3597.

Wang, Y., McAllister, T. A., Rode, L. M., Beauchemin, K. A., Morgavi, D. P., Nsereko, V. L., IwaAsa, A. D. \& YanG, W. (2001). Effects of an exogenous enzyme preparation on microbial protein synthesis, enzyme activity and attachment to feed in the Rumen simulation technique (Rusitec). British Journal of Nutrition 85, 325-332.

YanG, W. Z., Beauchemin, K. A. \& Rode, L. M. (1999). Effects of an enzyme feed additive on extent of digestion and milk production of lactating dairy cows. Journal of Dairy Science 82, 391-403. 